\title{
An Overall Perspective on Banking Regulation ${ }^{12}$
}

\author{
By \\ Xavier Freixas ${ }^{3}$ \\ and \\ Anthony M. Santomero ${ }^{4}$
}

\begin{abstract}
We survey the theory of banking regulation from the general perspective of regulatory theory. Starting by considering the different justifications of financial intermediation, we proceed to identify the market failures that make banking regulation necessary. We then succinctly compare how the analysis of regulation compares in the domains of banking and industrial organization. Finally we analyse why a safety net for banks could be part of banking regulation and how it can be structured in an efficient way.
\end{abstract}

JEL CODES: G21, G28

Keywords: banking regulation, efficiency, financial stability, banking supervision

\footnotetext{
${ }^{1}$ The views expressed here are those of the authors and do not necessarily reflect those of the Federal Reserve System

${ }^{2}$ Financial support from DGESIC (PB-1057) is acknowledged

${ }^{3}$ Universitat Pompeu Fabra

${ }^{4}$ The Wharton School, University of Pennsylvania, and the Federal Reserve Bank of Philadelphia
} 


\section{Introduction}

Recently, the theory of banking regulation has undergone important changes. This has been the consequence of a number of compounding effects that have been occurring in the financial sector. First among these is on-going financial innovation, which has caused a virtual revolution in both financial instruments and markets. As a result, the markets and institutions that must be regulated have changed substantially over time. At the same time, regulation has evolved, as the regulators have learned the lessons from the recent spat of banking crises. As a consequence of these experiences, regulation has become more sophisticated, with the introduction of capital requirements and more complex restrictions on operating procedures.

At the same time, a second force of change has emerged in academic circles where a new paradigm central to our understanding of both financial markets and the regulation of these markets has been developing. Asymmetric information theory, a setting in which economic agents are presumed to operate in a world of incomplete and, at times biased, information, has developed. In our view, this framework is perfect to adapt to the issues central to the theory of banking. The insights that this theory offers have had a profound effect on our view of regulation. In this chapter we review the impact of imperfect information on our understanding of why financial markets exist, how they operate, and how best to regulate them. In the first part of this chapter (section 2) we start by identifying the market failures that are specific to the banking industry. Namely, we will consider, first, the types of imperfections characteristic of financial markets, then turn to the justification of financial intermediaries, so as to provide a better understanding of what are the main market failures in the financial industry. This will allows us to draw a coherent view of the role of regulation in the financial intermediation industry. The benefits from constructing this overall perspective will be derived from showing how apparently disconnected regulatory measures, such as capital requirements, law and finance or the GlassSteagall Act are interwoven.

The second part of this chapter (section 3) considers the design of regulation as well as its impact, and reviews the working of the main regulatory instruments, as well as the effects they had on the banks' behavior. 


\section{Market failure in the banking industry}

\subsection{Financial intermediation and banking regulation}

Contemporary banking theory offers a rigorous perspective on financial market structure and the role played by banking institutions. It argues that financial intermediaries emerge endogenously to solve financial market imperfections that spring from various types of asymmetric information problems. These institutions arise to exploit such market information imperfections for economic gain. In other words, financial institutions begin where the conditions for the application of the Modigliani-Miller theorem ends.

Regulation is the rational response of the government to these new market failures. A lack of response would result in either financial institutions excessive risk taking or in the growth and development of monopoly power, which is a natural economic outcome of such market circumstances.

With this perspective, banking regulation is ultimately justified by an appeal to the existence of market failure, without which such regulation would be unnecessary and Pareto optimality in the allocation of resources would obtain. However, there is an additional level of complexity when one considers banking regulation. Its mere existence changes the nature of the information problem because the regulator itself is an interested party. This alters the information environment in an important way, and makes the attainment of Pareto efficiency more difficult (Stiglitz (1994)).

In our view, therefore, one cannot discuss banking, its existence, its regulation, or the effect of such regulation, in a world without financial imperfections. In fact, in order to study banking regulation, one must start, as Bhattacharya, Boot and Thakor (1998) do, by examining why financial intermediaries exist in the first place, and follow all the implications from there. This is the perspective we adopt hereafter. 


\section{Figure 1}

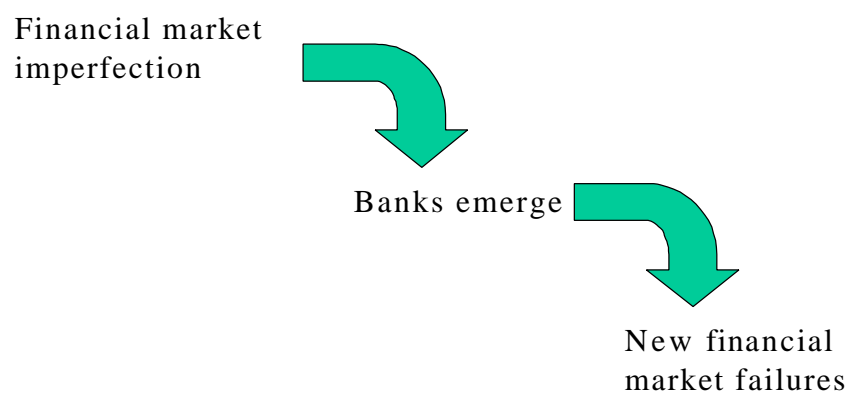

\subsection{The reasons for intermediation}

In contemporary theory, the question of why financial intermediaries exist has received several answers, which can be seen as complementary in nature. Contrary to the earlier work of Fama (1980), which argued that banks exist because of the economies of scope between transferring claims on property and offering investment opportunities, and other earlier transactions cost approaches recounted in Santomero (1984), most modern theories assume some form of information imperfection in the financial markets that permits the emergence of an intermediary sector.

Four alternative theories have developed to explain why banks exist in response to these financial market imperfections. Each has an alternative role for the banking firm.

1. Screening of potential borrowers. The first justification offered for the emergence of a banking institution suggests that banks screen potential clients ex ante on behalf of their depositors. They do so either because they are better at screening such potential customers than the average investor (Grossman and Stiglitz (1980)), or because they are merely the delegated monitor of proposals, on behalf of a large number of interested parties (Campbell and Kracaw (1980)). In the same vein, Ramakrishnan and Thakor (1983) 
establish the existence of economies of scale in the screening process that are due to asymmetric information. The creation of banks, which are akin to coalitions of firms, could therefore alleviate the adverse selection problem.

2. Monitoring customers' actions and efforts. Monitoring theory is closely related to the previous rationale, but focuses more on the monitoring of borrowers' actions after loan approval. Models here have concentrated on the actual use of borrowed funds (Boot and Thakor (1993)), effort involved (Allen and Gale (1988)) and ex post outcome revelation (Diamond, (1984), Gale and Hellwig (1985)).

3. Providing liquidity risk insurance. The next justification, offered by Diamond and Dybvig (1983), suggests that agents face uncertainty on the timing of their consumption. They are better off in a banking contract that allows for some ex ante insurance than buying financial securities. While such entities might prove unstable, as McCulloch (1986) suggests, the rationale proves quite robust and in fact dates back to the late $19^{\text {th }}$ century.

4. Creating a Safe Asset. According to Gorton and Pennacchi $(1990,1993)$, banks may also emerge as an optimal security design. Bank deposits provide an investment in a safe asset, which is not affected by information in the financial markets, and is a feasible, efficient asset in optimal portfolio decisions.

Each of these theories offers justification for the emergency of an intermediary sector. Yet, existence is only a portion of the problem. Optimality requires that the market provides banks with the right incentives, i.e., Pareto optimal incentives, to screen, monitor, invest and produce a well-diversified safe deposit. This issue is often summarized by the question "who monitors the monitor?" It is only if the right incentives for banks to monitor firms exist that an efficient banking system will emerge. This is because, with incorrect incentives, market failures will occur in the absence of regulation of individual banks and the banking system as a whole. Such failures reduce social welfare and real economic activity, as Gertler (1988) adequately reviews. In addition, self-fulfilling bank runs may occur and lead to either ex ante or ex post dominated asset allocation. The fundamental issues here are closely associated with the contributions of Diamond and Dybvig (1983) and Calomiris and Khan (1991). 


\subsection{Market failures in the financial industry}

Economics has enumerated several negative effects of market failure in the financial sector. These negative impacts may result from the breakdown of either the laissez-faire financial sector without intermediaries and/or an unregulated banking sector. Their importance has direct relevance to the need for regulation and the beneficial impact of effective deployment of government resources to reduce such losses. In addition, some have argued that further beneficial social effects may accrue to optimally engineering resource allocation within the financial sector. These benefits, of course, can only derive from the value weighting of winners and losers associated with any proposed non-Pareto improving regulation. Here, we briefly survey the three types of alleged market failures that are addressed by the regulation of the banking sector.

\subsubsection{Monetary liquidity costs}

In contemporary financial systems aggregate liquidity is the responsibility of the central bank. It was this justification that first led them to have a monopoly over money creation (Friedman and Schwartz (1963)). If the central bank is responsible for the assurance of sufficient liquidity, part of its responsibility must undoubtedly include overseeing the money markets and therefore the regulation of financial intermediaries. Essentially this is the logic behind the systemic stability role delegated to central banks throughout developed markets, e.g., Federal Reserve, Bank of England, and the European Central Bank.

The central banks oversight of the financial sector is derived from the intermediary sector's role in the asset transformation listed above. Banks have illiquid assets and allegedly liquid liabilities. Transformation is dependent upon prudent asset allocation and the expectation of trading within the sector. In addition, both assets and liability specify a nominal monetary return (nominal contracting). This payments system structure is an efficient approach to providing the transfer of property claims. Only Fama (1980) disagrees, with his assertion that bank deposits are private contracts with different levels of risk. To most others, bank deposits are money, and 
efficient consumption allocation is dependent upon a liquid and efficient operating financial structure.

\subsubsection{The cost of bank failure}

A bank failure generates negative externalities for two reasons. It destroys specific capital and it may lead to further contagion losses in the system. On the one hand, a bank closure reduces economic welfare because there is a loss of the relationship with the bank's clients and the specific knowledge of management and risk preferences (As illustrated by Slovin et al (1999)) for the cost of the Continental Illinois failure). On the other hand, the costs of such closures are more acute, because the failure may spread throughout the banking system, amplifying the negative effects on unrelated intermediaries.

The very justifications of financial intermediation point out the high risk of contagion. In the screening and monitoring justifications, a bank failure may signal a weakness in bank assets in general (Gorton (1988), Chari and Jaggannathan (1988). In addition, if systemic, it may cause depositors to question the entire system as it questions the incentives of any bank to adequately monitor its borrowers. If banks are seen as lacking incentives to monitor, they will engage in fraudulent operations and excessive risk taking (Campbell and Kracaw (1980)). In such a case, a bank failure may lead depositor in other banks to run the bank and withdraw their deposits, at a high liquidation cost, in spite of the soundness of the affected secondary bank. In any case, if one bank fails, this may produce a perfectly rational (Bayesian) updating of the assessment of any other bank risk and a generalized withdrawal of deposits. If safe assets are presumed to be a central reason for banking firms' value and existence, such a bank failure would deprive the banking system itself of its rationale. Hence, for all four reasons for intermediation, contagion or domino effects are likely and detrimental to economic welfare and prove detrimental to the potential outcome of an errant system.

Yet, it is traditionally accepted that contagion may occur both because of a change in depositors' expectations on bank returns and because their financial interdependence resulting from the net of reciprocal claims that are generated by the interbank borrowing, the payment 
system and OTC derivatives. Consequently, a bank failure may affect both the real and the perceived stability of the banking system. This is often referred to as the inherent instability of the financial system. As a consequence, social welfare is intimately involved with the regulatory environment and the way in which a bank crisis is handled. It may or may not trigger a domino effect on the rest of the banking system.

\subsubsection{Enhancing efficiency}

Independent of the features that are specific to the banking industry, the standard market failures that affect any other industry must also be taken into consideration. In particular, the inefficiency created by market power is relevant here as well. The complexity, though, is that market power may have been generated by the very regulatory measures that are designed to cope with concerns over liquidity and bankruptcy risk.

The efficient operation of the financial sector depends critically upon confidence that financial markets and institutions operate according to rules and procedures that are fair, transparent and place the interests of customers first. This confidence is a public good. It increases the flow through financial markets and the effectiveness with which financial markets allocate resources across time and space. But this public good may be underproduced, because the private returns to firms that adhere to strict codes of conduct are likely to be less than the social returns. Unethical firms may be able to free ride on the reputation established by ethical firms and take advantage of the relative ignorance of clients in order to boost profits. The primary efficiency rationale for conduct of business and conflict of interest rules is to correct this perverse incentive.

Finally, financial markets provide critical information that helps to coordinate decentralized decisions throughout the economy (Santomero and Babbel, (1997)). Better access to high quality information by participants on a timely basis will allow financial markets to provide better pricing signals and to allocate resources more efficiently. This applies not only to information regarding issuers of financial instruments, but also to financial institutions themselves 
and the products they sell. Disclosure standards thus also serve to improve overall economic efficiency as well as a consumer protection rationale.

Efficiency would also be enhanced if regulators were required to justify each new regulation with a careful assessment of its costs and benefits. This requirement is an obligation of Britain's new Financial Services Authority. It should be a fundamental part of the regulatory process everywhere.

\subsection{Other social objectives}

Governments are often tempted to exploit the central role played by the financial sector in modern economies in order to achieve other social purposes. Budget constrained governments frequently use the banking system as a source of off-budget finance to fund initiatives for which they chose not to raise taxes or borrow. Over time this politically connected lending can have a devastating impact on the efficiency and safety and soundness of the financial system. We have learned this from the experience of many central and eastern European countries and the recent Asian banking crisis (Santomero 1997, 1998). Nonetheless, regulation is frequently used for this purpose.

The housing sector is often favored by government intervention in the financial sector. For example, the United States has chartered financial institutions with special regulatory privileges that specialize in housing finance. It has also promoted home ownership by extending implicit government guarantees to securities backed by housing mortgages and by allowing homeowners to deduct mortgage interest on their income taxes. In addition, until its interest rate ceilings were eliminated, the United States favored housing lenders by allowing them to pay their depositors a slightly higher interest rate than banks could pay their depositors, a policy that had the effect of enhancing the funds made available to finance housing.

Governments also channel credit to favored uses in other ways. Most countries subsidize financing for exports, sometimes through special guarantees, insurance, or through special discount facilities at the central bank. They also implement special programs to develop credit lines to fund small businesses. Many countries also require their financial institutions to 
lend to certain regions or sectors. Since the enactment of the Community Reinvestment Act in 1977, the United States has required its commercial banks and savings institutions to serve the credit needs of low-income areas.

The United States has also used regulation to achieve the social objective of preventing large concentrations of political and economic power within the financial sector, especially among banks. Until recently, the United States has restricted the ability of banking organizations to expand across state lines. And, until the end of 1999, restrictions continued limiting bank participation in non-banking activities.

Finally, many members of the Organization of Economic Cooperation and Development have imposed reporting requirements on banks and some other financial institutions in an effort to combat money laundering associated with the drug trade and organized crime. In the United States, for example, banks are required to report all currency transactions of $\$ 10,000$ or more. Currently, Congress is considering even more stringent reporting requirements that have raised serious concerns about violations of privacy rights. Similarly the new Financial Services Authority in the United Kingdom (David (1998)) has adopted the objective of "preventing ... financial businesses being used for the purposes of financial crime."

\subsection{The equilibrium level of effective regulation}

By focusing on the optimal regulatory mechanism to cope with a specific market imperfection, we may fall prey to a naïve view of the world. Powerful regulators act in the best interest of society, and the regulated banks will submissively abide by the regulation. In fact, a more realistic view should be one in which regulation is an economic game with each agent developing its own strategy given its own objectives. Not only is it natural to assume that the regulators pursue their own objective in a world where there powers are limited by the legal framework, but it is also crucial to take into account that banks will react to regulation by developing new strategies, like introducing new financial innovations. Kane's now well-known "regulatory dialectic" and "regulatory captive" models captures this dynamic, as does Kroszner's political economy view of regulatory motivation (Kane (1995) and Kroszner (1997)). 
We have attempted to describe these complex relationships between the welfare maximizing principal, the regulator (its agent), and the regulated agent (the banks) in Figure 2. Adding this perspective to the real life dynamics of regulation will introduce a series of important limitations to the likely outcome of regulation.

The first box in Figure 2 recalls the different options regarding the choice of a type of regulation. While in the banking industry the main bulk of regulation stems from public regulation, some areas are left to the industry itself which establishes the standards to be applied. For instance, the level of training for a bank officer could be completely unregulated or established by the industry itself .

The second box describes the choice regarding how many regulators will implement the policy chosen, and their respective mandates. Whether because of institutional constraints or in order to enhance their efficiency, the overall regulatory problem has been delegated to different agencies. These agencies, e.g., a central bank, may have incentives to focus on one dimension (say financial stability) rather than on another that may also be relevant to the public interest (e.g. the efficiency and competitiveness of the banking industry).

Once this structure of regulatory power is set, the regulatory agency incentives have to be considered, as illustrated in the third box. Even if we consider the case of effective public regulation, regulators may view their role, consciously or unconsciously, as one of a defender of the regulated industry's best interests. In addition, the letter of the law, as well as existing institutional structures may be manipulated to affect the impact of regulation on interested parties, or at least to change the focus of specific aspects of it. This leads to a new kind of second-best problem. More generally, the problem that is faced is the one of the regulatory agency's objective function.

Fourth, and perhaps most importantly, the regulatory framework will change the incentives and strategies of the regulated sector. This is a feedback that the regulator must anticipate and should factor into its regulatory design. Two important cases of this feedback are illustrated in the articles reproduced in this volume. The paper by Kroszner and Rajan, considers the incentives of banks before the Glass-Steagall Act. They show that, in spite of banks having 
incentives to underwrite equity in order to pay back loans which would otherwise have been at a loss, this did not occur. The second paper also considers the feedback the change in banks strategies has on the banking industry equilibrium. In particular, the issue arises in connection with the disclosure of loan losses by banks. As argued by Aghion, Bolton and Fries(1999, reproduced in this volume), since a bank is always able to renew a non performing loan, the regulator has to be careful not to set too high penalties for loan losses, because otherwise all banks will renew their all their loans, possibly creating an even higher cost for the economy.

Finally, competition among banks, subject to the imposed regulatory constraint, may have "general equilibrium" effects that may differ from the ones expected at the individual level. If so, the sought after goal may not be achieved in the aggregate, even if regulation is well-meaning and fosters preferred firm-level incentives. For example, restrictions on credit allocation may favor certain sectors but the regulation may so tax the banking sector as to make it noncompetitive and ineffective in providing needed resources to the target sector of the economy. 


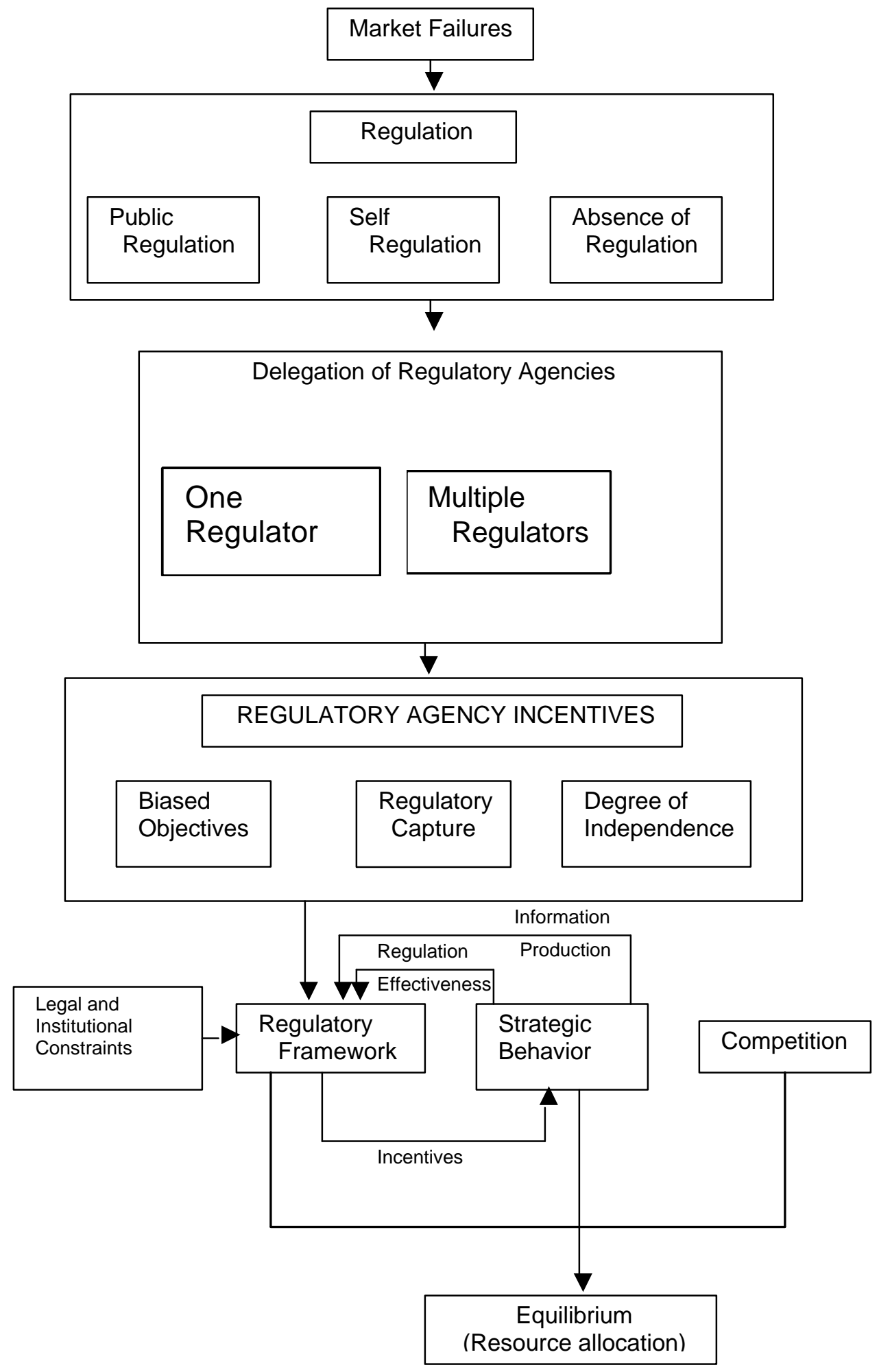


In choosing the optimal regulatory design, regulators have to face the overall equilibrium and the channeling of financial resources that will ultimately emerge. Yet, they will also have to consider both their own constraints and the limitations that they are facing when they compete with other markets and regulators, either internationally (as well illustrated by the euromarket developments) or even nationally when the boundaries of the different agencies attributions are sufficiently close.

Figure 2 attempts to capture this aggregate dynamic by offering a schematic representation of the impact of both market failures and regulation on the financial sector. It proves less than simple, with considerable indirect impacts of both the disease (market failure) and the cure (regulation).

\section{Regulatory design and its impact}

\subsection{The safety net}

Since bank failures appear to have strong externalities in terms of liquidity, bankruptcy costs, and asset destruction, an important part of banking regulation is designed to prevent bank failures or, at least, to limit their effects. This is referred to as "the safety net" that surrounds the banking system and protects bank customers. How extensive this safety net should be is still a matter of debate, among economists and politicians alike. In some countries, for example, France or Japan, allowing a bank to fail and its unsecured creditors to suffer the consequences of the bank decisions is deemed unacceptable. In others, for example, the US and New Zealand, it is an event anticipated in regulation.

From a theoretical perspective, the safety net is generally justified as a mechanism to protect small, uninformed economic agents. Yet, the safety net may be extended further, to other financial stakeholders in order to avoid the undesirable externalities of a bank's bankruptcy 
enumerated above. Although some elements of the safety net, like deposit insurance are explicit and duly regulated, others, such as Lender of Last Resort intervention, are implicit and difficult to assess.

Nonetheless, in all cases the existence of the safety net has externalities on the firms' risk taking, altering the choice calculus by changing the state-dependent returns and fostering high-risk activity. Ultimately, in the case of a bail-out, taxpayers bear the cost of this incorrect risk weighting. It is the cost of creating a safety net, which may have desirable aggregate and structural stability effects. The appropriate height of the safety net will involve a weighing of these costs of its assistance against the benefits of the implied financial stability it brings. Evaluation of any one part of the safety net also involves consideration of the costs and benefits of each type of safety net enhancement. It is to this that we now turn.

\subsubsection{Deposit insurance}

Deposit insurance is a way to limit bank fragility. If the deposit insurance scheme is credible, the issue of bank runs in the Diamond-Dybvig setting is solved. However, since banks' creditors are their customers, the protection is usually justified by an appeal to those who are not well informed. Still, the extent and form of this portion of the safety net varies from one country to another. This raises several issues for the banking industry (Santomero and Trester (1997), Freixas and Rochet (1997)),

The method to protect these liability holders is best understood if we recall that the rights the bank acquires by accepting an insured deposit in the presence of deposit insurance include a put option written by the Deposit Insurance Agency (Merton (1977)), or, to be more precise, a callable put option (Acharya and Dreyfus (1988)). The value of this right to the bank is monotonic in volatility and maximized at the maximum level of risk. Thus, bank risk taking behavior is altered, and if it is not fully observable, deposit insurance will lead to excessive risk absorption.

The price of such an option should depend on the level of risk (volatility of the underlying), as well as the ex ante capital ratio of the insured entity (which determined the strike price). It follows directly that flat or uniform deposit insurance pricing will lead to subsidizing risky 
banks at the expense of safe institutions. However, given the information environment, it is difficult to establish whether deposit insurance is fairly priced, and the extent of the distortion in resource allocation associated with the subsidy or tax on individual institutions. Given the opaque nature of assets on bank balance sheets, some of the determinants of the correct option value will be private information. This point leads some to conclude that it is impossible to obtain fair deposit insurance pricing (Chan, Greenbaum and Thakor (1992)).

This feature of the actuarial problem has lead to a more global normative approach of banks regulation. Design mechanisms have shifted from relating a financial institution deposit insurance premium to its level of instantaneous risk to one in which sufficient capital is required to ensure that the government's option is reasonably far "out of the money" (Giammarino et al. (1993), Freixas and Gabillon (1999)).

\subsubsection{Capital requirements}

The above logic has led to considerable interest in optimal capital regulation (Santomero (1991)). However, the task of imposing an appropriate capital standard to justify the fixed or variable insurance premium is little easier than setting up a risk-related deposit insurance scheme. Theoretically, Sharpe (1978) illustrated the isomorphic nature of the two issues, and Koehn and Santomero (1980) and Kim and Santomero (1988) outline the instantaneously optimal risk weighted capital ratios. The contribution of Rochet (1992, reproduced in this volume) provides the most consistent model of the feedback of capital requirement regulation on the banks portfolio choice. He remarks that limited liability implies that the distribution of returns has to follow a truncated distribution, and using this distribution shows, first, that capital requirements on each assets may induce the bank to select an inefficient portfolio; second, he proves that the absence of a minimum capital requirement, independent of the bank's portfolio, may induce the bank to become risk lover when the returns it obtains are low, as its profit function is concave as a consequence of its limited liability.

The Basle Accord of 1988 obviously falls far short of these optimal structures. However, this should not be a surprise. With real-time variations in bank risk-taking, and uncertain 
volatilities associated with given credit and/or market risk positions, most have concluded that optimal capital regulation is infeasible. While advances have been proposed, and are currently under review (BIS (1998)) little hope is offered that such remedies can or will address the imperfect information and moral hazard problems associated with any feasible bank capital regulation regime.

This has led to three different attempts to address the issue of appropriate capital. The first, associated with Kuester and O'Brien (1990) and Kupiec and O'Brien (1997) suggests that the banking firm be required to self-disclose its appropriate level of capital, based upon its more exact knowledge of the market and credit risk contained in its portfolio. The firm will, then, be held to this pre-commitment level on an ex post basis. If capital proves to be insufficient for observed volatility, ex post the regulators will impose a pecuniary penalty for violation. While this approach had immediate appeal, its implementation has proved no easier than earlier regulations surrounding risk-based capital requirements. While experiments have been conducted, a workable solution has proved illusory and the approach has been all but abandoned.

Interest then turned to a change in regulation that would require that banks fulfill a specified part of their capital requirement with subordinated debt, as a mechanism to increase market discipline. Subordinated debt, as a junior claim, serves as a buffer against losses by the deposit insurer (Benston and Kaufman (1998)) and Benston et al (1989)). Subordinated debt has some of the characteristics of patient money, because it typically has a maturity greater than one year and can not be redeemed quickly during a crisis. Subordinated creditors have strong incentives to monitor bank risk taking and impose discipline. They are exposed to all downside risk that exceeds shareholder equity, but their potential gain on the upside is contractually limited. In contrast to shareholders that may choose higher points on the risk-return frontier, subordinated creditors, like the deposit insurer, generally prefer safer portfolios and are likely to penalize banks that take significant risks.

The market discipline of traded subordinated debt is a much quicker and more precise way of controlling bank risk than regulatory measures. A falling price of subordinated debt can alert other creditors about the condition of the bank or actions of the managers, creating a broad 
market reaction. Moreover, market prices are more forward looking than regulatory examinations and may provide regulators with valuable information on the market's perception of the risk taken by institutions (Horvitz (1983), Calomiris and Litan (2000)).

When bank risk increases unexpectedly, banks may not have to pay higher rates or face possible quantity discipline until their subordinated debt matures. For this reason, subordinated debt proposals generally require that the bank stagger the maturities of debt issue so that a modest proportion matures each quarter. In this way, market discipline through price and quantity sanctions may be effective and informative, but sufficiently limited in magnitude to provide time for crisis resolution or orderly termination.

Critics of subordinated debt requirements emphasize that subordinated debt holders face the same informational asymmetry problems that the deposit insurer faces, but without the authority to conduct detailed examination (Kane (1995)). They also question whether secondary markets in subordinated debt would be deep enough to provide reliable price signals. They, therefore, prefer to de-emphasize the market's role in risk-containment in favor of further advances in self-regulation.

Their cause has recently received increased credibility with the new BIS proposal for the use of internal models to set capital standards, along with existing rating agencies (BIS (1998)). While there is much interest in the approach, its capitulation to the asymmetric information problem leaves some regulators unsatisfied. Not atypically, they would prefer both own model capital standards and significant regulatory oversight as part of any new system of capital regulation. In the end, they believe the regulator or central bank will still be performing the role of liquidity facility. They, therefore, have an obligation to maintain an appropriate level of oversight and comfort in the prudence of management's positions ex ante.

\subsubsection{Lender of last resort}

The term Lender of Last Resort (LOLR) refers to liquidity facilities that are open to banks. The classical theory argues that this function is reserved for lending to illiquid but solvent 
institutions, using good collateral and at a premium price. In fact, the reality of the use of the term Lender of Last Resort in many cases is quite different, although politically justified (See Freixas, Giannini, Hoggarth and Soussa (2000)). This is because although the LOLR facilities are supposed to solve a failure in the market provision for liquidity, banks in financial distress have often used them as a method to obtain a rescue package. This is the case because it is, at times, nearly impossible to distinguish ex ante (and even occasionally ex post) whether a loan is to solve an illiquidity problem being experienced by the institution or a solvency problem. Nevertheless, in a well-developed financial market, the Central Bank provides the necessary liquidity to such institutions even though this is only a minor part of their activity.

The provision of liquidity to the banking system as a whole is quite a relevant issue, since, as we have seen, there is an inherent instability of the banking sector directly related to the justification of banks. Not only are banks confronted with informational asymmetries but they also have to deal with illiquid assets and liquid liabilities. The provision of liquidity to the banking system will be an essential task, therefore, in order to maintain banking stability.

Central Banks may provide liquidity to banks through different channels. The classical justification of the lender of last resort dates from the 19th century and is based on the presumption that the money market may fail to allocate liquidity to solvent banks that require it. Therefore, it was not clear whether the Lender of Last Resort was designed for monetary stability reasons, or for financial stability ones. Today's perspective is quite different, because the money market provides liquidity to any solvent institution (Goodfriend and King (1988)).

\subsubsection{Bail-out policy and bank closure}

Whether they act under cover, or use the LOLR alibi to perform a rescue operation, the central bank bail-out policy does exist (Goodhart and Schoenmaker (1993), Santomero and Hoffman (1999)). It is characterized, first, by the fact that "too large to fail" banks are systematically rescued (See Hughes and Mester (1993)); Second, by the fact that the bail-out policy is never announced ex ante (constructive ambiguity), which is justified by the idea that free 
riding will be limited. These bailout operations are the result of the concern of the central bank for the externalities created by a bank's failure. Although there has been a general trend towards limiting the rescue packages, it is not credible that rescue packages will be denied to insolvent banks whose bankruptcy would have a large negative externalities. Freixas (1999) has recently examined the cost-benefit analysis of bail-outs and emphasizes the need to take the social cost of bail-outs into consideration. Even then, he concludes that it will be worth rescuing "too large to fail" institutions and using a mixed strategy to decide on the smaller institutions who have complied with regulatory requirements.

The concern about the externalities of a bank bankruptcy, however, tends to ignore the fact that the costs of bank externalities are the result of bankruptcy resolution legislation. As such, they are, at least partially, endogenous to the regulatory environment. Consequently, any attempt to establish a regulatory regime, which minimizes bankruptcy cost, must include consideration of the mechanism for orderly liquidation. Yet, the closure of financial institutions is a rather involved issue for three interrelated reasons. First, the regulator is constrained by the existing national bankruptcy code. Second, it is constrained by enacted banking regulation, and third, it is constrained by the information available at the time of the liquidation decision. Finally, and above all, the regulator may maximize its own objective function which may not coincide with welfare maximization.

The discrepancy between the regulators objectives and the efficient decisions has been discussed at length, but a crystal clear illustration is provided by Kane(1990) which establishes the costs implied by the excessively generous bail-out policy followed after the Saving and Loans crisis. Boot and Thakor(1993) provide a theoretical argument that justifies forbearance: since a bank closure damages a regulator's reputation, in a reputational equilibrium regulators will always tend to implement excessively lenient bank closure policy that will be.

Mailath and Mester (1994) emphasize the fact that the regulators objective function may be a restriction to regulation policy. This is indeed the case as a regulator thread have to be credible and therefore a bank will never be penalized for his past breaches of regulation if the penalty worsens the regulator outcome. 
Repullo (2000) has illustrated the second point, regarding the limits set by enacted banking regulation, by examining how the delegation of the rights to close or rescue a bank could be made more efficient by making different parties responsible for the decision in different circumstances. The central bank could determine the closure point when the amount withdrawn by depositors in the first period is small and the deposit insurance agency in cases of potential large withdrawals and bank runs.

The information constraint faced by the regulatory body in charge of the liquidationcontinuation decision (labeled "information production" in Figure 2) is modeled in a simple elegant way in Aghion, Bolton and Fries (1999, this volume). They argue that banks have the option to roll over loans that would have to be written off and in this way hide the real extent of their losses. In this case, they show that if the regulator is excessively tough and systematically liquidates banks in financial distress, the banks will react by hiding their losses. The optimal scheme is only obtained when the regulator is willing to bail out the insolvent bank in some cases.

However, the effect of these operations is to increase the safety net, thus covering uninsured depositors. As a consequence, it causes excessive risk-taking. The creditors that should be in charge of limiting the banks risk by exerting market discipline implying larger interest rates for the uninsured liabilities and, in particular, subordinated debt have no incentive to monitor the bank's risk. Calomiris and Kahn model clarified this point.

Nevertheless, no matter how negative the effects of the bail-out mechanism may be, it is clear that the existence of such a mechanism is essential in order to solve systemic risk crises. As we have mentioned, in the absent of any rescue procedure, the existence of interbank credit, with unsecured interbank market and a payment system, which is in general an efficient way to cope with liquidity shocks, may create a contagion channel that could trigger a systemic crises out of an individual bank bankruptcy (Allen and Gale (2000)) and Freixas, Parigi and Rochet (2000))

We are, at the end, left in a world of second best, where perfect regulation is infeasible and spillover from necessary regulatory tools has deleterious effects on the equilibrium character of the system. 


\section{$4 \quad$ References}

Acharya, S. and J.F. Dreyfus, "Optimal Bank Reorganization Policies and the Pricing of Federal Deposit Insurance". Journal of Finance, 44(5), 1.314-34, 1988.

Aghion, P., P.Bolton and S. Fries, "Optimal Design of Bank Bailouts: The Case of Transition Economies". Journal of Institutional Theoretical Economics, 155, 51-70, 1999.

Allen, F. and D. Gale, "Optimal Security Design". Financial Innovation and Risk Sharing. Allen, F., D. Gale, Cambridge and London: MIT Press, p157-97, 1994. Previously published: 1988.

Allen, F. and D. Gale, "Financial Contagion". Journal of Political Economy, forthcoming Bank for International Settlements, 2000; "Reducing Foreign Exchange Settlement Risk: A Progress Report”. Basle, July, 1998.

Allen, F. and D. Gale, “Optimal Security Design”. Review of Economic Studies, 50, p 639-46, 1998

Bagehot, W. "Lombard Street: A Description of the Money Market." London, H.S. King, 1873.

Benston, G.J., D. Brumbaugh, J. Guttentag, R. Herring, G. Kaufman, R. Litan, and Ken Scott, Blueprint for Restructuring America's Financial Institutions, Washington D.C.: The Brookings Institution, 1989.

Benston, G. J. and G. G. Kaufman, "Deposit Insurance Reform in the FDIC. Improvement Act: The Experience to Date". Economic Perspectives, Federal Reserve Bank of Chicago, 1998.

Berger, A. N., D. Hancock and J.C. Marquardt, "A Framework for Analyzing Efficiency, Risks, Costs, and Innovations in the Payments Systems". Journal of Money Credit and Banking. 28, Pt.2, 696-732, 1996.

Bhattacharya, S., A.Boot, and A. Thakor, "The Economics of Bank Regulation". Journal of Money, Credit \& Banking. 30 (4). p 745-70. November 1998.

Boot, A.W.A. and A. Schmeits, "Market Discipline and Incentive Problems in Conglomerate Firms with Applications to Banking". Journal of Financial Intermediation, 1999.

Boot, A. W A and A. Thakor. "Self Interested Bank Regulation". American Economic Review, 83(2), 206-12. May 1993. 
Boot, A. W A and A.Thakor "Security Design". Journal of Finance. 48(4), p1349-78. September 1993.

Bordo, M.D, "The Lender of Last Resort: Alternative Views and Historical Experience." Federal Reserve Bank of Richmond Economic Review. 76(1): 18-29, 1986.

Calomiris, C. and R. Litan, "Financial Regulation in a Global Marketplace". Brookings Wharton Papers, Litan and Santomero, ed., forthcoming 2000.

Calomiris, C., "The IMF's Imprudent Role as Lender of Last Resort", The Cato Journal. $17, \mathrm{~N}^{\circ} 3,1999$.

Calomiris, C.; W and C. M. Kahn, "The Role of Demandable Debt in Structuring Optimal Banking Arrangements". American Economic Review. 81 (3). p 497-513. June 1991.

Calomiris, C. W. and C. M. Khan, "The Efficiency of Self-Regulated Payment Systems: Learning from the Suffolk System". Journal of Money Credit and Banking. 28, Pt.2, 766-797, 1996.

Campbell, T. and W. A. Kracaw, "Information Production, Market Signalling, and the Theory of Financial Intermediation," Journal of Finance. 35, p863-82, September 1980.

Chan, Y.S., S.I. Greenbaum and A.V. Thakor, "Is Fairly Priced Deposit Insurance Possible?", Journal of Finance. 47, 227-45, 1992.

Chari, V.V. and R. Jaggannathan, "Banking Panics, Information and Rational Expectations Equilibrium". Journal of Finance. 43(3), 749-61, 1988.

Chung, E.J. and A.M. Santomero. "Evidence in Support of Broader Bank Powers", Financial Markets, Institutions and Instruments, (formerly Salomon Brothers Monograph series in Finance and Economics), 1992.

De Bandt, O. and P. Hartmann, "Systemic Risk: A Survey". Working Paper European Central Bank, 1999.

Davies, H., "Why Regulate?" Henry Thornton Lecture, City University Business School, November 4, 1998.

Diamond, D. W., "Financial Intermediation and Delegated Monitoring," Review of Economic Studies. 51, p 393-414, 1984.

Diamond, D. and P. Dybvig, "Bank Runs, Deposit Insurance, and Liquidity", Journal of Political Economy. 91(3), 401-9, 1983. 
Di Noia, C. and G.di Giorgio, "Should Banking Supervision and Monetary Policy Tasks Be Given to Different Agencies ?", CONSOB and Universitá la Sapienza, 1999.

Fama, E., "Banking in the Theory of Finance", Journal of Monetary Economics. 6 (1): 39-57, 1980.

Flannery, M., "Financial Crises, Payment System Problems, and Discount Window Lending", Journal of Money, Credit and Banking. 28: 4, 804-824, 1996.

Freixas, X. and E. Gabillon, "Optimal Regulation of a Fully Insured Deposit Banking System”, Journal of Regulatory Economics. 16 (2). p 111-34. September 1999.

Freixas, X. J. C. Rochet, "Microeconomics of Banking." Cambridge and London: MIT Press., 1997.

Freixas, X., B. Parigi and J. C. Rochet, "Systemic Risk, Interbank Relations and Liquidity Provision by the Central Bank", Journal of Money Credit and Banking 32(3, part 2), August 2000, 611-638

Freixas, X., C. Giannini, G. Hoggarth and F. Soussa, "The Lender of Last Resort: A Review of the Literatue". Journal of Financial Services Research, 18(1), October 2000, p.63-87

Freixas, X., "Optimal Bail-Out, Conditionality and Constructive Ambiguity", Financial Market Group Discussion Paper 237, London School of Economics, 1999.

Friedman, M. and A. Schwartz, “A Monetary History of the United States: 1867-1960", 1963.

Gale, D. and M. Hellwig, "Incentive-compatible Debt Contracts: The One-Period Problem". Review of Economic Studies. 52, p 647-63, 1985.

Gertler, M., "Financial Structure and Aggregate Economic Activity: An Overview", Journal of Money, Credit, and Banking. 20 (3), (August, Part 2), 1988.

Giammarino, R.M., T.R. Lewis and D. Sappington, "An Incentive Approach to Banking Regulation". Journal of Finance, 48, 1.523-42, 1993.

Goodhart, C.A.E. and D. Schoenmaker, "Should the Functions of Monetary Policy and Bank Supervision be Separated?’. Oxford Economic Papers, 39, 75-89, 1995.

Goodhart, C.A.E. and D. Schoenmaker, "Institutional Separation Between Supervisory and Monetary Agencies", en F.Bruni (comp.), Prudential Regulation, Supervision and Monetary Policy, Milan, Universita Bocconi, 1993. 
Goodfriend, M. and R. King, "Financial Deregulation, Monetary Policy and Central Banking, in Restructuring Banking and Financial Services in America, edited by W. Haraf and R.M. Kushmeider, AEI Studies, 481, Lanham Md: UPA, 1988.

Gorton, G., "Banking Panics and Business Cycles". Oxford Economic Papers. 40, pp 751-78, 1988.

Gorton, G. and G. Pennacchi, "Financial Intermediaries and Liquidity Creation," Journal of Finance. 45, pp. 49-71, 1990.

Gorton, G. and G. Pennacchi, "Security Baskets and Index-Linked Securities". Journal of Business. 66 (1). p 1-27. January 1993.

Gorton, G. and A. Winton, "Liquidity Provision, the Cost of Bank Capital, and the Macroeconomy". Mimeo, University of Minnesota, 1999.

Grossman, S. J. and J. Stiglitz, 1980, "On the Impossibility of Informationally Efficient Markets". American Economic Review, 70, 393-408.

Holmstrom, B. and J. Tirole, "Financial Intermediation, Loanable Funds and the Real Sector". Quarterly Journal of Economics, 112, 663-691, 1997.

Horvitz, P., "Deposit Insurance after Deregulation," Proceedings of the $9^{\text {th }}$ Annual Conference of the Federal Home Loan Bank of San Francisco, December 1983.

Huang H. and C. Xu, "Financial Institutions, Financial Contagion and Financial Crises", IMF and London School of Economics, 1998.

Hughes J. and L. Mester, "A Quality and Risk Adjusted Cost Function for Banks: Evidence on the "Too Big to Fail Doctrine". Journal of Productivity Analysis, 4(3) 293$315,1993$.

Kane, E. J., "Principal-Agents Problems in S\&L Salvage". Journal of Finance, 45(3), 755-64, 1990.

Kane, E. J., "Three Paradigms for the Role of Capitalization Requirements in Insured Financial Institutions”. Journal of Banking \& Finance, 19, pp. 431-459, 1995.

Kim, D. and Anthony M. Santomero, "Risk in Banking and Capital Regulation". Journal of Finance, 43 (5), p 1219-33, December 1998.

Koehn, M. and Anthony M. Santomero, "Regulation of Bank Capital and Portfolio Risk". Journal of Finance, 35 (5), p 1235-44, December 1980. 
Kroszner, R. S. "The Political Economy of Banking and Financial Regulation in the United States". The Banking and Financial Structure in the NAFTA Countries and Chile. Von Furstenberg, George M., ed., Boston; Dordrecht and London: Kluwer Academic. P200-212. 1997.

Kroszner, R. S. and R. Rajan "Is the Glass-Steagall Act Justified?" American Economic Review, 845(4), 810-32,1993

Kupiec, Paul H. and James M. O'Brien. "The Pre-Commitment Approach: Using Incentives to Set Market Risk Capital Requirements". [Working Paper] Board of Governors of the Federal Reserve System, Finance and Economics Discussion Paper Series: 1997/14. p 52. March 1997.

Kuester, K.A. and J.M. O'Brien, "Market Based Deposit Insurance Premiums". Proceedings of the Conference on Bank Structure and Competition, Federal Reserve Bank of Chicago, pp. 62-95, 1990.

Lóránth, G., "Financial Conglomerates: Innovations, Scope-Expansion and Incentives", Universities London and Libre of Bruxelles, 1999.

Mailath G. and L. Mester, "A Positive Analysis of Bank Closure". Journal of Financial Intermediation, 3(3) 272\}-99, 1994.

McCulloch, J Huston. "Bank Regulation and Deposit Insurance". Journal of Business. 59(1), p79-85, January 1986.

Merton, R., "An Analytic Derivation of the Cost of Deposit Insurance and Loan Guarantees". Journal of Banking and Finance, 1, 3-11, 1977.

Miron, J., "Financial Panics, the Seasonality of the Nominal Interest Rate, and the Founding of the Fed". American Economic Review 76(1): 125-40, 1986.

Ramakrishnan, R.T.S. and A. Thakor (1983) "Information reliability and a theory of financial intermediation" Review of Economic Studies, 51,415-32

Repullo, R., "Who Should Act as Lender of Last Resort? An Incomplete Contracts Model ". Journal of Money Credit and Banking, 1999.

Rochet, J.C. "Capital Requirements and the Behaviour of Commercial Banks", European Economic Review, 36, 1137-78, 1992

Rochet, J. C. and J. Tirole, "Interbank Lending and Systemic Risk". Journal of Money Credit and Banking, 28, Pt.2, 733-762, 1996.

Santomero, Anthony M., "Modeling the Banking Firm," Journal of Money, Credit, and Banking. 16, Part 2, pp. 576-602, 1984. 
Santomero, A.M, "The Bank Capital Issue", Financial Regulation and Monetary Arrangements after 1992, Fratianni, M., Wihlborg, C. and T.D. Willett, Editors. Economic Analysis Series, Vol. 204 Amsterdam; London; New York, and Tokyo: North Holland; distributed in the U.S. and Canada by Elsevier Science, New York, p 61-77, New Holland Press, 1991.

Santomero, Anthony M., "Effective Financial Intermediation", Policy-Based Finance and Alternatives: East Asian Lessons for Latin America and the Caribbean, Kim B. Staking, Editor, Inter-American Development Bank, 1997.

Santomero, Anthony M. and David Babbel, Financial Markets, Instruments and Institutions, Irwin Publications, 1997.

Santomero, Anthony M. and Jeffrey Trester, "Structuring Deposit Insurance for a United Europe", European Financial Management, June 1997.

Santomero, Anthony M., "The Regulatory and Public Policy Agenda for Effective Intermediation in Post Soviet Economies", in Financial Sector Reform and Privitization in Transition Economies (7), 153-175, J. Doukas, V. Murinde and C. Wihlborg, Editors, Elsevier Science Publishers B.V. 1998.

Santomero, Anthony M. and P. Hoffman. "Problem Bank Resolution: Evaluating the Options", International Banking Crises, Large Scale Failures, Massive Government Interventions, Benton E. Gup, Editor, Greenwood Publishing, 1999.

Sharpe, William F., "Bank Capital Adequacy, Deposit Insurance, and Security Values." Journal of Financial and Quantitative Analysis. 13, p 701-18, November 1978.

Slovin, Myron B.; Sushka, Marie E. and John A. Polonchek, "An Analysis of Contagion and Competitive Effects at Commercial Banks". Journal of Financial Economics. 54 (2). p 197-225. October 1999.

Stiglitz, Joseph E., 'The Role of the State in Financial Markets'. In Proceedings of World Bank Annual Conference on Development Economics. Washington, D.C.: World Bank, 1994. 